\title{
Decreased Post-Cesarean Endometritis Following Povidone Iodine-Vaginal Preparation
}

\author{
Alaa Raheem Kareem (FICMS) ${ }^{1}$, Wasan Munim(FICMS, CABOG) ${ }^{2}$, Niran \\ Kamel(FICMS $)^{3}$, Mustafa Rasool Aal- Saleh(FICMS $)^{4}$, Sarah Abdulkareem Ali Al- \\ Dujaili $(\mathrm{MBCHB})^{5}$ and Mohammed Luay Subhi $(\mathrm{MBCHB})^{6}$
}

Abstract

Background: Despite the use of several strategies to prevent post-Cesarean complications including wound infections and endometritis, they remain high morbidities.

Objective: To assess the pre-Cesarean preparation of the vagina with povidone iodine as a preventive measure against post-cesarean wound infection and endometritis.

Patients and Methods: A case-control study conducted on 200 pregnant women who prepared for elective Cesarean section. The operations were conducted either with standard classical abdominal scrub alone (as control group) or vaginal povidone iodine preparation in addition to the standard abdominal scrub. Each woman was followed up post-operatively for development of fever, endometritis, and wound infection, duration of postoperative antibiotics administration, and postoperative stay.

Results: Post-Cesarean endometritis developed in $6 \%$ of women who received a vaginal preparation pre-operatively and $15 \%$ of the controls. $30 \%$ of control women and $20 \%$ of women in the treatment group had post-operative febrile illness. Wound infections were uncommon complications that occurred only in two percent of the control patients and one percent of patient in the treatment group.

Conclusion: Pre-operative vaginal treatment with povidone iodine decreased the risk of postCesarean endometritis. However, this protocol doesn't decrease the whole risk of postoperative wound infection or fever.

Keywords: Post-Cesarean Endometritis, Povidone Iodine-Vaginal.

Corresponding Author: drmustafarasool2003@yahoo.com

Received: $7^{\text {th }}$ October 2019

Accepted: $28^{\text {th }}$ November 2019

DOI:https://doi.org/10.26505/DJM.18025001007

\footnotetext{
1,3,5,6 Al-Kadhimiya Teaching Hospital - Baghdad -Iraq

${ }^{2}$ Al-Hakim General Hospital- Baghdad -Iraq

${ }^{4}$ Medical City Department - Baghdad Teaching Hospital -Baghdad -Iraq
} 


\section{Introduction}

Cesarean delivery is the delivery of a fetus through incision in the abdominal wall (laparotomy) and in the uterine wall (hysterotomy) [1]. From the years 1970 to the 2007, the Cesarean section delivery rate in the USA rose from about 4.5 percent of all deliveries to about 31.8 percent [2]. However the reasons of this continuous increase in the rates of cesarean sections are not well understood, some explanations include that the greater percentage women are nulliparous, who are in favor of cesarean delivery in addition to the fact that the mean maternal age is increasing and older age women, especially in nulliparous, are at higher risk of cesarean section delivery[3].

Puerperal infection is a general term used to define any type of bacterial infection in the genital tract post-delivery [4][5]. The type of delivery (normal or Cesarean) is the most important and significant risk factor for puerperal infection [6]. Rehospitalization rates for wound complications and endometritis were increased significantly in women undergoing a planned primary cesarean delivery compared with those having a planned vaginal birth[7] while Compared with cesarean section delivery, endometritis following vaginal delivery is relatively less common[8-10].Persistent post-delivery fever is seldom due to antimicrobial-resistant bacteria, or due to any drug side effects. The woman may be discharged home after she has been afebrile for at least 24 hours [11, 12].
Prevention of Infection: Over the years, a number of strategies have been tested to prevent or at least mitigate the severity of postpartum infections, this includes: Perioperative Antimicrobial Prophylaxis, prenatal Treatment of Vaginitis and some Operative Technique such as allowing the placenta to separate spontaneously compared with removing it manually lowers the risk of infection. Exteriorizing the uterus to close the hysterotomy may decrease febrile morbidity [13].

Povidone iodine: It has a bactericidal effect and it is effective against bacteria, fungi and even spores. The bactericidal effect occurs in seconds and it could be due to inactivation of the vital cytoplasmic substrates that are very important for bacterial viability[14-15]. Both pathological and histological studies didn't find any adverse effect of povidone-iodine on the wound healing [16]. However, no evidence showing that povidone-iodine pretreatment could aid in wound healing. Researchers have studied the effects of povidone-iodine on several cellular components in the mechanism of wound healing. In spite of the in vitro cytotoxicity effect, in vivo studies showed that povidoneiodine doesn't interfere with wound healing, especially when it is used in concentrations of $1 \%$ or less [17-18]. Povidone iodine also has an effect on bacterial enzymes and exotoxins, which might cause increased damage. A study on the resistance to antiseptic in 20 bacterial strains showed that povidone-iodine killed all the bacteria within about 20 seconds [19]. This study aimed to 
assess the application pre-Cesarean preparation of the vagina with povidoneiodine to decrease the occurrence of postcesarean endometritis in women undergoing elective cesarean delivery.

\section{Patients and Methods}

A case-control study was conducted in the obstetrics and gynecology department at $\mathrm{Al}$ Kadhymia Teaching Hospital, Baghdad, Iraq. From October 2018 to August 2019, the study included 200 pregnant women who underwent an elective cesarean delivery at $\geq$ 37 weeks gestational age and had no obvious infections (temperature $38^{\circ} \mathrm{C}$ or greater). Complete history and physical examination including speculum and pelvic exam to exclude leaking liquor and the cervical dilatation. Assessment of the gestational age by ultrasound, non-stress test, hemoglobin estimation and general urine exam were done for all patients.

Exclusion criteria were: 1- Emergent cesarean 2- Planned cesarean hysterectomy 3- Preterm delivery 4- Fetal distress 5Chorioamnionitis 6- Ruptured amniotic membranes 7- Cervical dilation more than 3 cm. 8- Placenta Previa 9- Active genital herpes, 10 - Allergy to iodine-containing solutions, 11- Medical complications like D.M, HT, anemia, and patient on steroid therapy.

Patients were randomly assigned to allocation group. All subject were assigned to study group those who received vaginal cleansing with povidone-iodine and abdominal scrub, and the controlled group who received a standard abdominal scrub only.

The primary study aimed at post-cesarean endometritis, other maternal complications included febrile illness (persistent fever higher than $38^{\circ} \mathrm{C}$ for more than 24 hours after surgery, without a lower abdominal tenderness and infections any where else), infection in the wound (i.e. wound-drained purulent material), blood cultures positive, length of the hospital stay, and the number of days of antibiotics therapy.

Endometritis was defined as temperature 38 $\mathrm{C}$ or more on any two post-operative days (exclude the first 24 hours after delivery). In addition, diagnosis should include one of the these signs:

a) Tender uterus on palpation

b) Vaginal discharge of foul-smelling

c)Tachycardia

d)Leukocytosis (higher than 12,000/ mm3)

\section{Statistical analysis}

The data are collected, organized and tabulated by using computer software Statistics Package for Social Science (SPSS) version 17. The results are expressed in form of numbers, percentages and Pearson Chisquare which was statistically significant at p.value less than 0.05 . The figures are done by using Microsoft office excel 2007.

\section{Results}

Two-hundred patients were recruited into the study.one hundred subjects assigned to receive a standard abdomen scrub only (control group), and one hundred subjects received additional vaginal preparation (study group). Comparison of two groups 
didn't demonstrate a significant difference in the patient's demographics (age, parity, and gestational age), pregnancy-history, obstetric history, or maternal medical conditions.

Regarding maternal age in study group $25 \%$ were $<20$ years and $75 \% \geq 20$ years. In control group $25 \%$ were $<20$ years and $75 \%$

Table (1): Distribution of test and control subjects according to age and parity

\begin{tabular}{|c|c|c|c|c|c|c|}
\hline \multirow[t]{2}{*}{ Subjects } & \multicolumn{2}{|c|}{ Age } & \multicolumn{2}{|c|}{ Parity } & \multirow[t]{2}{*}{ Total } & \multirow[t]{2}{*}{ P value } \\
\hline & $<20$ years & $\geq 20$ years & primi & multipara & & \\
\hline Patients & (25) $25 \%$ & (75) $75 \%$ & (20) $20 \%$ & (80) $80 \%$ & 100 & $>0.05$ \\
\hline Controls & (25) $25 \%$ & $\overline{c(75) 75 \%}$ & (30) 30\% & 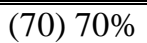 & 100 & $>0.05$ \\
\hline
\end{tabular}

Post-cesarean endometritis found in $(15 \%)$ of control group and in $(6 \%)$ of patients who received pre-operative vagina-scrub $(\mathrm{P}$ value $<0.05)$. Febrile illness occurred in $(30 \%)$ of control group and $(20 \%)$ in the study group (P value> 0.05). Wound infection was iuncommon complication found in $(2 \%)$ of control group and in $(1 \%)$ the study group (P value $>0.05)$. Postoperative length of stay $>3$ day (20\%) in $\geq 20$ years ( $\mathrm{P}$ value $>0.05$ ). Regarding parity $20 \%$ were primi in study group and $80 \%$ were multipara. In control group $30 \%$ were primi and $70 \%$ were multipara ( $\mathrm{P}$ value $>0.05)$, Table (1).
(70) $70 \%$

control group and (5\%) in the studygroup ( $\mathrm{P}$ value $>0.05)$. Post-operative length of stay $\leq$ 3 day $(80 \%)$ in the control group and $(95 \%)$ in the study group ( $\mathrm{P}$ value $>0.05)$. Numbers of days on antibiotics $\leq 3$ days $(25 \%)$ in control group and $(50 \%)$ in the study group( $\mathrm{P}$ value $<0.05)$ ). Numbers of days on antibiotics $>3$ days $(75 \%)$ in control group and $(50 \%)$ in the study group ( $\mathrm{P}$ value < 0.05). As shown in Table (2). 
Table (2): Post-cesarean section complications (endometritis, fever, and infection) in the study groups

\begin{tabular}{|c|c|c|c|c|c|c|}
\hline & & & \multicolumn{2}{|l|}{ Study groups } & \multirow[b]{2}{*}{ Total } & \multirow[b]{2}{*}{$\mathrm{P}$ value } \\
\hline & & & Study group & $\begin{array}{l}\text { Control } \\
\text { group }\end{array}$ & & \\
\hline \multirow{4}{*}{ Endometritis } & \multirow{2}{*}{ Present } & No. & 6 & 15 & 21 & \multirow{6}{*}{0.043} \\
\hline & & $\%$ & $6.0 \%$ & $15.0 \%$ & $10.5 \%$ & \\
\hline & \multirow{2}{*}{ Absent } & No. & 94 & 85 & 179 & \\
\hline & & $\%$ & $94.0 \%$ & $85.0 \%$ & $89.5 \%$ & \\
\hline \multirow{2}{*}{\multicolumn{2}{|c|}{ Total }} & No. & 100 & 100 & 200 & \\
\hline & & $\%$ & $100.0 \%$ & $100.0 \%$ & $100.0 \%$ & \\
\hline \multirow{4}{*}{$\begin{array}{l}\text { Febrile } \\
\text { morbidity }\end{array}$} & \multirow{2}{*}{ Present } & No. & 20 & 30 & 50 & \multirow{6}{*}{0.141} \\
\hline & & $\%$ & $20.0 \%$ & $30.0 \%$ & $25.0 \%$ & \\
\hline & \multirow{2}{*}{ Absent } & No. & 80 & 70 & 150 & \\
\hline & & $\%$ & $80.0 \%$ & $70.0 \%$ & $75.0 \%$ & \\
\hline \multirow{2}{*}{\multicolumn{2}{|c|}{ Total }} & No. & 100 & 100 & 200 & \\
\hline & & $\%$ & $100.0 \%$ & $100.0 \%$ & $100.0 \%$ & \\
\hline \multirow{4}{*}{$\begin{array}{l}\text { Wound } \\
\text { infection }\end{array}$} & \multirow{2}{*}{ Present } & No. & 1 & 2 & 3 & \multirow{6}{*}{0.990} \\
\hline & & $\%$ & $1.0 \%$ & $2.0 \%$ & $1.5 \%$ & \\
\hline & \multirow{2}{*}{ Absent } & No. & 99 & 98 & 197 & \\
\hline & & $\%$ & $99.0 \%$ & $98.0 \%$ & $98.5 \%$ & \\
\hline \multirow{2}{*}{\multicolumn{2}{|c|}{ Total }} & $\begin{array}{l}\text { Total } \\
\text { No. }\end{array}$ & 100 & 100 & 200 & \\
\hline & & $\%$ & $100.0 \%$ & $100.0 \%$ & $100.0 \%$ & \\
\hline \multirow{4}{*}{$\begin{array}{l}\text { Post- } \\
\text { operative } \\
\text { length of } \\
\text { stay }\end{array}$} & \multirow{2}{*}{$>3$ days } & No. & $\overline{5}$ & 20 & 25 & \multirow{6}{*}{0.002} \\
\hline & & $\%$ & $5.0 \%$ & $20.0 \%$ & $12.5 \%$ & \\
\hline & $<3$ dow & No. & 95 & 80 & 175 & \\
\hline & $\leq 3$ days & $\%$ & $95.0 \%$ & $80.0 \%$ & $87.5 \%$ & \\
\hline \multirow{2}{*}{\multicolumn{2}{|c|}{ Total }} & No. & 100 & 100 & 200 & \\
\hline & & $\%$ & $100.0 \%$ & $100.0 \%$ & $100.0 \%$ & \\
\hline \multirow{4}{*}{$\begin{array}{l}\text { Number of } \\
\text { days on } \\
\text { antibiotics }\end{array}$} & \multirow{2}{*}{$\leq 3$ days } & No. & 50 & 75 & 125 & \multirow{6}{*}{0.001} \\
\hline & & $\%$ & $50.0 \%$ & $75.0 \%$ & $62.5 \%$ & \\
\hline & & No. & 50 & 25 & 75 & \\
\hline & $>3$ days & $\%$ & $50.0 \%$ & $25.0 \%$ & $37.5 \%$ & \\
\hline \multirow{2}{*}{\multicolumn{2}{|c|}{ Total }} & No. & 100 & 100 & 200 & \\
\hline & & $\%$ & $100.0 \%$ & $100.0 \%$ & $100.0 \%$ & \\
\hline
\end{tabular}

\section{Discussion}

The use of vaginal anti-septics is not a new in gynecology. Since the 1970s, it has been shown that povidone iodine scrub of the vagina before surgery (Vaginal or whether abdominal hysterectomy) had lower postoperative infections[20]. Post-partum wound, pelvic, and endometrial infections are most often poly-microbial. The predominant are 
vaginal organisms, in addition to skin and rectal contaminants. During and after cesarean section, the uterus is still open in continuum to the vagina, also the surgeon's hand, reaching below the presenting part, becomes direct contact with vagina. In such cases, the vaginal organisms are in direct contact with the abdominal cavity, uterus, and also the abdomen incision. Cleaning of all the body surfaces that are in contact with the surgical operation is essential to the aseptic techniques. Although such preparation doesn't give in a sterile field, but it tend to decrease the bacteria and fungal micro-organisms naturally present in the skin and in the mucosa [14].

In this study; the incidence of endometritis in a study group was $6 \%$ and in control group 15\% which is consistent with the results of Star et al [21]. Within their study population, they showed a benefit of a pre-operative vaginal wash just before the cesarean. The rate of post-cesarean endometritis is significantly lowered in those women who were prepared with abdominal and vagina povidon iodine as compared to those with an abdomen scrub alone. A vaginal povidone iodine preparations; might decrease endometrium exposure to the number of bacterial species at the time of uterus incision.

In agreement with this study is the study done by Haas et al. in 2010. The primary outcomes were composite of postoperative fever, sepsis, endometritis, re-admission, and wound infection. About 9\% developed this composite, with less women in the vaginal cleansing group (6.5\%) compared with control group (11.7\%) [22]. The difference in the reported post-operative rates of endometritis might be due to the procedure and type of materials used in vaginal wash itself or could be the amount of antiseptic that was used could have effect on the infectious outcome.

In the current study; the post cesarean endometritis decrease with use pre-operative vaginal preparation with povidone-iodine, while Reid et al [23] found that vaginal scrub didn't have an effect on the rate of postoperative endometritis, fever, or woundinfection.

This study used prophylactic antibiotics at time of umbilical cord clamping and this is consistent with result of Walts etal [24], in their study that parenteral antibiotics reduce postoperative endometritis of approximately $50 \%$ and in spite of the use of prophylactic antibiotics; failure of prophylaxes is common which could be due to a change in the vaginal flora or resistance to antibiotics.

\section{Conclusions}

Pre-operative vaginal treatment with povidone iodine decreased the risk of postCesarean endometritis. However, this protocol doesn't decrease the whole risk of post-operative wound infection or fever.

\section{Recommendations:}

Vagina preparations with povidone iodine before the Cesarean section decreases the risk of post-operative endometritis with using parenteral antibiotics prophylaxis at the time of clamping the umbilical cord. 


\section{References}

[1]American College of Obstetricians and Gynecologists, Task Force on Cesarean Delivery Rates: Evaluation of cesarean delivery. June 2000.

[2]Hamilton BE, Martin JA, Ventura SJ: Births: Preliminary Data for 2007. National Vital Statistics Reports, Vol 57, No 12. Hyattsville, Md, National Center for Health Statistics, 2009.

[3]MacDorman MF, Menacker F, Declercq E: Cesarean birth in the United States: Epidemiology, trends, and outcomes. Clin Perinatol 35(2):293, 2008.

[4]American College of Obstetricians and Gynecologists: Fetal lung maturity. Practice Bulletin No. 97, September 2008.

[5]Berg CJ, Chang J, Callaghan WM, et al: Pregnancy-related mortality in the United States, 1991-1997. Obstet Gynecol 101:289, 2003 [PMID: 12576252].

[6]Deneux-Tharaux C, Carmona E, BouvierColle $\mathrm{MH}$, et al: Postpartum maternal mortality and cesarean delivery. Obstet Gynecol 108:541, 2006 [PMID: 16946213] . [7]Declercq E, Barger M, Cabral HJ, et al: Maternal outcomes associated with planned primary cesarean births compared with planned vaginal births. Obstet Gynecol 109:669, 2007 [PMID: 17329519].

[8] Maberry MC, Gilstrap LC, Bawdon RE, et al: Anaerobic coverage for intra-amnionic infection: Maternal and perinatal impact. Am J Perinatol 8:338, 1991 [PMID: 1760067].

[9] Baksu A, Kalan A, Ozkan A, et al: The effect of placental removal method and site of uterine repair on postcesarean endometritis and operative blood loss. Acta Obstet Gynecol Scand 84(3):266, 2005.

[10]Tita ATN, Hauth JC, Grimes A, et al: Decreasing incidence of postcesarean endometritis with extended-spectrum antibiotic prophylaxis. Obstet Gynecol 111:51, 2008 [PMID: 18165392].

[11]Costantine MM, Rahman M, Ghulmiyah L, et al: Timing of perioperative antibiotics for cesarean delivery: A metaanalysis. Am J Obstet Gynecol 199(3):301.e1, 2008.

[12]Chaim W, Bashiri A, Bar-David J, et al: Prevalence and clinical significance of postpartum endometritis and wound infection. Infect Dis Obstet Gynecol 8:77, 2000 [PMID: 10805361].

[13]Atkinson MW, Owen J, Wren A, et al: The effect of manual removal of the placenta on post-cesarean endometritis. Obstet Gynecol 87:99, 1996 [PMID: 8532276].

[14]Osborne NG, Wright RC. Effect of preoperative scrub on the bacterial flora of the endocervix and vagina. Obstet Gynecol 2005;50:148-50.

[15]Cape BR ,Dobson P .Bailliere's Nurses Dictionary 18 th ed.

[16]Hagglund L ,Christensen KK, Christensen P Effect of a strict preoperative hygienic routine on the rate of infections following cesarean section.ur $\mathrm{J}$ Obstet Gynecol Reprod Bio.1986 Nov;23(3-4):18794.

[17]Mayer DA ,Tsapogas MJ.Povidoneiodine and wound healing a critical review.Wounds 1993;5:14-23.

[18]Lanker Klosssner B, Widmer H.R, Frey F. Non de/e! pnwnt of resistant" to bacteria 
during hospital use of povidoneiodine Derl1latolo/(y 1997; 195 (suppl) 103.

[19]Koing n ,Reimer K ,Fleieher W ,Koing $\mathrm{W}$.Effects of beta isodnna on the parameters of host defence. Demwrology 1997;195(suppl2):42-8.

[20]Haeri AD, Kloppers LL, Forder AA, Baillie P. Effect of different pre-operative vaginal preparations on morbidity of patients undergoing abdominal hysterectomy. S Afr Med J 1976;50:1984-6.

[21]Starr RV, Zurawski J, Ismail M: Preoperative vaginal preparation with povidone-iodine and the risk of postcesarean endometritis. Obstet Gynecol 105:1024, 2005 [PMID: 15863540] . [22]Haas DM, Pazouki F, Smith RR, et al. Vaginal cleansing before cesarean delivery to reduce postoperative infectious morbidity: a randomized controlled trial. Am J Obstet Gynecol 2010;202:310.e1-6.

[23]Reid VC, Hartmann KE, McMahon M, Fry EP. Vaginal preparation with povidone iodine and postcesarean infectious morbidity: a randomized controlled trial. Obstet Gynecol 2001;97:147-52.

[24]Walts DH, Hillier SL, Eschenbach. Upper genital tract isolates at delivery as predictors of post-cesarean infections among women receiving antibiotic prophylaxis. Obstet Gynecol2001;77:287-92. 